\title{
MOTIVASI PETANI DALAM BUDIDAYA TANAMAN CABAI DI DESA RAANAN BARU KECAMATAN MOTOLING BARAT KABUPATEN MINAHASA SELATAN
}

\author{
MOTIVATION OF FARMERS IN CULTIVATING CHILI \\ PLANTS IN RAANAN BARU VILLAGE MOTOLING BARAT DISTRICT \\ SOUTH MINAHASA REGENCY
}

\author{
$\underline{\text { Dolfina Krois }}^{(1)}$, Ribka M. Kumaat ${ }^{(2)}$, Theodora M Katiandagho ${ }^{(2)}$ \\ 1) Mahasiswa Program Studi Agri-Sosioekonomi, Fakultas Pertanian, Universitas Sam Ratulangi, Manado \\ 2) Dosen Program Studi Agribisnis, Fakultas Pertanian, Universitas Sam Ratulangi, Manado \\ *Penulis untuk korespondensi: dolfinakrois801@gmail.com
}

\begin{tabular}{lr}
\hline Naskah diterima melalui e-mail jurnal ilmiah agrisosioekonomi@unsrat.ac.id & : Kamis, 11 Maret 2021 \\
Disetujui diterbitkan & $:$ Jumat, 28 Mei 2021 \\
\hline
\end{tabular}

\begin{abstract}
This study aims to determine the motivation of farmers in chili cultivation and the factors that influence the motivation of farmers in cultivating chili plants in Raanan Baru Village. The data analysis used in this research is descriptive analysis using the Likert scale. This research was conducted for three months, from January to March 2020. The research took place in Raanan Baru Village, Motoling Barat District, South Minahasa Regency. The data used in this study are primary data and secondary data. Primary data obtained through interviews with farmers who cultivate chili plants as research samples. Secondary data were obtained from the village office, the Motoling Barat sub-district office, South Minahasa district The results showed that the motivation of farmers in cultivating chili plants in Raanan Baru Village was found that sociological motivation had a high interpretation value of 443.3 percent in the hope that it could fulfill their economic needs. Sociological motivation arose because of the desire to strengthen harmony and exchange opinions among chili farmers. Economic motivation has a high value interpretation with a percentage of 464 percent. Economic motivation arises because of the desire to get a higher income which can have a positive impact.
\end{abstract}

Keywords : motivation; farmers; cultivating; chili plant

\begin{abstract}
ABSTRAK
Penelitian bertujuan untuk mengetahui motivasi petani dalam budidaya tanaman cabai di Desa Raanan Baru Kecamatan Motoling Barat Kabupaten Minahasa Selatan. Analisis data yang digunakan dalam penelitian ini adalah analisis deskriptif dengan menggunakan Skala likert. Penelitian ini dilakukan selama tiga bulan yaitu dari bulan Januari sampai Maret tahun 2020. Penelitian bertempat di Desa Raanan Baru Kecamatan Motoling Barat Kabupaten Minahasa Selatan. Data yang digunakan dalam penelitian ini adalah data primer dan data sekunder. Data primer diperoleh melalui wawancara kepada petani yang membudidayakan tanaman cabai sebagai sempel peneliti. Data sekunder diperoleh dari kantor desa, kantor Kecamatan Motoling Barat Kabupaten Minahasa Selatan. Hasil penelitian menunjukkan bahwa motivasi petani dalam budidaya tanaman cabai di Desa Raanan Baru didapatkan yaitu motivasi sosiologis memiliki nilai interpretasi yang tinggi yaitu 443,3 persen dengan harapan dapat memenuhi kebutuhan ekonominya. Motivasi sosiologis muncul karena adanya keinginan untuk mempererat kerukunan dan bertukar pendapat sesama petani cabai. Motivasi ekonomi memiliki interpretasi nilai yang tinggi dengan persentase 464 persen. Motivasi ekonomi muncul karena adanya keinginan untuk mendapatkan pendapatan yang lebih tinggi dan dapat membawa dampak positif.
\end{abstract}

Kata Kunci : motivasi; petani; budidaya; tanaman cabai

Agrisosioekonomi : Jurnal Transdisiplin Pertanian (Budidaya Tanaman, Perkebunan, Kehutanan, Peternakan, Perikanan Ekonomi dan Teknologi Pangan serta Teknologi Pertanian). 


\section{PENDAHULUAN}

\section{Latar Belakang}

Indonesia merupakan negara agraris, artinya pertanian masih memegang peranan penting pada seluruh sistem perekonomian nasional, untuk itu pembangunan pertanian menjadi salah satu hal penting yang harus dilakukan. Pembangunan sektor pertanian sudah selayaknya tidak hanya berorientasi pada produksi atau terpenuhinya kebutuhan pangan saja tetapi juga harus mampu meningkatkan taraf hidup masyarakat terutama petani.

Motivasi merupakan salah satu unsur penting dalam peningkatan produktivitas petani. Motivasi diartikan sebagai faktor-faktor yang mengarahkan dan mendorong perilaku atau keinginan seseorang untuk melakukan kegiatan yang dinyatakan dalam bentuk usaha yang keras atau lemah (Hariandja, 2002). Faktor yang mempengaruhi motivasi petani diantaranya ialah sosial (internal) yang terdiri dari sikap dan perilaku, pengetahuan (pendidikan), dan keterampilan terdapat hubungan yang erat terkait dengan tingkat motivasi petani sedangkan pada faktor ekonomi (eksternal) yang terdiri dari penghargaan, mengikuti jejak sesama, pendapatan dan luas lahan juga terdapat hubungan yang erat terkait dengan tingkat motivasi petani.

\section{Konsep Motivasi}

Pengertian motivasi menurut Johansen, motivasi adalah dorongan dasar yang menggerakkan seseorang bertingkah laku. Dorongan ini berada pada diri seseorang yang menggerakkan untuk melakukan sesuatu yang sesuai dengan dorongan yang ada dalam dirinya.

\section{Faktor-Faktor yang Mempengaruhi Motivasi}

Secara garis besar faktor-faktor yang mempengaruhi motivasi dapat dikelompokkan menjadi faktor eksternal dan faktor internal. Faktor internal adalah faktor yang dapat mempengaruhi motivasi seseorang yang datangnya dari dalam diri seseorang. Faktor eksternal adalah faktor yang dapat mempengaruhi motivasi seseorang yang bersumber dari lingkungan luar yaitu lingkungan dimana terkait pencapaian tujuan tersebut.

\section{Motivasi Petani dalam Membudidayakan Tanaman Cabai}

Motivasi berarti sesuatu yang pokok, yang menjadi dorongan bagi seseorang untuk melakukan sesuatu (Kartono, 2003). Proses pertanian cabai ini ada dua cara yang dilakukan oleh petani dan memperkerjakan orang lain sesuai dengan luas lahan yang dimiliki petani yaitu :

1. Petani yang memiliki lahan yang sempit hanya dilakukan sendiri yang dibantu oleh anggota keluarganya, dan bagi petani yang memiliki lahan luas dikerjakan dengan memperkerjakan orang lain dengan sistim upah. Pengolahan lahan diawali dengan pembersihan lahan.

2. Motivasi petani menanam cabai dalam tingkat produksi dapat dilihat pada tingkat pendapatan dan penghasilannya yang sudah bisa memenuhi kebutuhan sehari-hari dan membiayai anak untuk sekolah dan juga bisa membeli peralatan rumah tangga dan membeli barang-barang yang berharga untuk sebagai simpanan.

\section{Teknik Budidaya Tanaman Cabai}

1. Pengadaan Benih

Pengadaan benih dapat dilakukan dengan cara membuat sendiri atau membeli benih yang telah siap tanam.

2. Pengolahan Tanah

Sebelum menanam cabai hendaknya tanah digarap lebih dahulu, supaya tanah-tanah yang padat bisa menjadi longgar, sehingga pertukaran udara di dalam tanah menjadi baik.

3. Penanaman

Pada penanaman yang benihnya langsung disebarkan di tempat penanaman.

4. Pemeliharaan Tanaman

Menurut (Hewindati, 2006) tanaman cabai yang telah ditanam harus selalu dipelihara.

5. Pengendalian Hama dan Penyakit

Menurut (Harpenas 2010), salah satu faktor penghambat peningkatan produksi cabai adalah adanya serangan hama dan penyakit yang fatal.

\section{Rumusan Masalah}

Bagaimana motivasi petani dalam budidaya tanaman cabai dan faktor apa yang mempengaruhi motivasi petani dalam budidaya tanaman cabai di Desa Raanan Baru Kecamatan Motoling Barat. 


\section{Tujuan Penelitian}

Penelitian ini bertujuan untuk mengetahui motivasi petani dalam budidaya tanaman cabai dan faktor apa yang mempengaruhi motivasi petani dalam budidaya tanaman cabai di Desa Raanan Baru Kecamatan Motoling Barat.

\section{Manfaat Penelitian}

Manfaat penelitian ini adalah sebagai berikut :

1. Untuk menambah wawasan pengetahuan dan meningkatkan pemahaman mengenai budidaya tanaman cabai.

2. Bagi petani di Desa Raanan Baru Kecamatan Motoling Barat, dapat memberikan solusi agar produktivitas tanaman cabai petani dapat meningkat.

\section{METODE PENELITIAN}

\section{Waktu dan Tempat Penelitian}

Penelitian yang dilaksanakan selama 3 bulan yaitu Januari sampai Maret 2020 dari persiapan hingga penyusunan laporan hasil penelitian. Penelitian bertempat di Desa Raanan Baru Kecamatan Motoling Barat Kabupaten Minahasa Selatan.

\section{Metode Pengumpulan Data}

Metode pengumpulan data dalam penelitian ini, dengan cara mengambil data primer dan data sekunder. Data primer adalah data yang diperoleh secara langsung dari lapangan melalui wawancara dengan menggunakan daftar pertanyaan kepada wanita usahatani tanaman hias. Sedangkan data sekunder adalah data yang diperoleh dari kantor desa.

\section{Metode Pengumpulan Data}

Data yang digunakan dalam penelitian ini adalah data primer dan data sekunder. Data primer diperoleh melalui wawancara kepada petani yang membudidayakan tanaman cabai dan data sekunder diperoleh dari kantor desa dan kantor kecamatan.

\section{Metode Pengambilan Sampel}

Pengambilan sampel dilakukan dengan cara random sampling teknik penentuan sampel dengan menggabungkan semua subjek-subjek didalam populasi sehingga semua subjek dianggap sama dan diambil secara acak. Pengambilan sampel diambil sebanyak 30 petani yang berusahatani tanaman cabai.

\section{Konsep Pengukuran Variabel}

A. Faktor-faktor yang mempengaruhi motivasi petani meliputi:

1. Faktor internal

a. Umur (tahun).

b. Tingkat Pendidikan (SD,SMP,SMA,).

c. Luas penguasaan lahan

2. Faktor eksternal

a. Lingkungan ekonomi yaitu ketersediaan sarana produksi dan adanya jaminan pasar

b. Keuntungan budidaya tanaman cabai yaitu tingkat kesesuaian potensi, tingkat ketahanan terhadap resiko dan tingkat penghematan waktu budidaya

3. Pendapatan yaitu perolehan dari kegiatan usahatani diukur dengan menghitung besarnya perolehan yang diterima petani.

B. Menurut Siagian (1999) dalam penelitian yang dilakukan oleh Dewandini (2010), dikemukakan bahwa motivasi dibagi menjadi 2 macam yaitu motivasi ekonomi dan motivasi sosiologi serta dapat diukur dengan lima indikator yaitu sebagai berikut :

1. Motivasi ekonomi, diukur dengan lima indikator yaitu :

a. Keinginan untuk memenuhi kebutuhan hidup keluarga.

b. Keinginan untuk memperoleh pendapatan yang lebih tinggi.

c. Keinginan untuk membeli barang-barang mewah.

d. Keinginan untuk memiliki dan meningkatkan tabungan.

e. Keinginan untuk hidup lebih sejahtera atau hidup lebih baik.

2. Motivasi sosiologis, diukur dengan lima indikator, yaitu:

a. Keinginan untuk menambah relasi atau teman.

b. Keinginan untuk bekerjasama dengan orang lain. 
c. Keinginan untuk mempererat kerukunan.

d. Keinginan untuk dapat bertukar pendapat.

e. Keinginan untuk dapat memperoleh bantuan dari pihak lain.

\section{Metode Analisis Data}

Analisis data yang digunakan dalam penelitian ini adalah analisis deskriptif dengan menggunakan Skala Likert. Skala yang digunakan untuk mengkuantitatifkan kuisioner adalah Skala Likert.

Skala Likert adalah skala yang di gunakan untuk mengukur Motivasi dalam Membudidayakan Tanaman Cabai. Untuk memberikan nilai terhadap jawaban dalam kuesioner dibagi menjadi tiga tingkat yang disusun bertingkat dengan memberikan bobot nilai (skor) sebagai berikut:

$\begin{array}{ll}\text { 1. S (Setuju) } & =3 \\ \text { 2. R (Ragu-ragu) } & =2 \\ \text { 3. TS (Tidak Setuju) } & =1\end{array}$

Dengan cara perhitungan nilai masingmasing pertanyaan:

Jumlah skor tiap kriteria = Capaian skor X

$$
\begin{aligned}
& \text { Jumlah responden } \\
& \text { S3 }=3 \times 30=90 \\
& \text { S2 }=2 X 30=60 \\
& \text { S1 }=1 X 30=30
\end{aligned}
$$

Jumlah skor ideal (skor tertinggi) yaitu 90 dan jumlah skor rendah yaitu 30 .

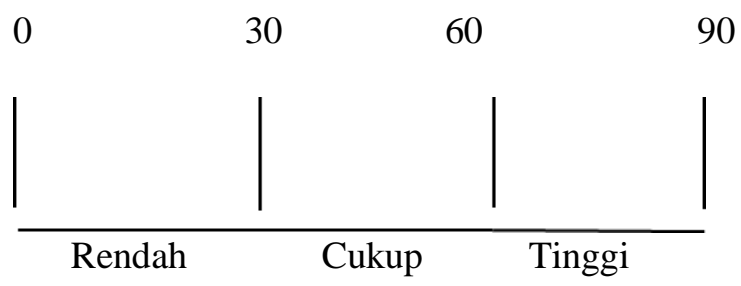

Cara perhitungan skor keseluruhan untuk mengetahui tingkat motivasi:

Jumlah skor seluruh kriterium = Capaian jumlah skor X Jumlah responden X Instrumen pertanyaan

$$
\begin{aligned}
& \mathrm{S} 3=3 \times 10 \times 30=900 \\
& \mathrm{~S} 2=2 \times 10 \times 30=600 \\
& \mathrm{~S} 1=1 \times 10 \times 30=300
\end{aligned}
$$

Jumlah skor ideal untuk keseluruhan pertanyaan yaitu 900 (Tinggi) dan jumlah skor rendah yaitu 300 (Rendah).

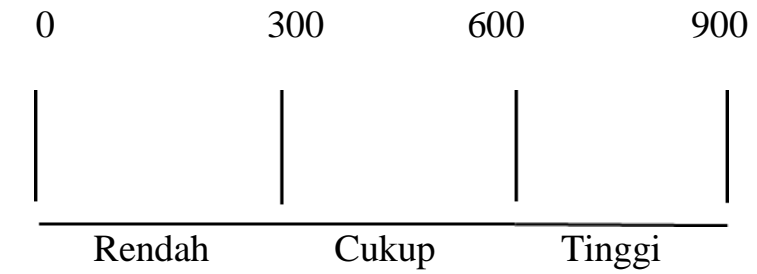

Tingkat Motivasi $=\frac{\text { Jumlah Skor Hasil Pengumpulan Data }}{\text { Jumlah Skor Ideal }(\text { Tertinggi })} \times 100 \%$

Dengan Intreprestasi nilai :

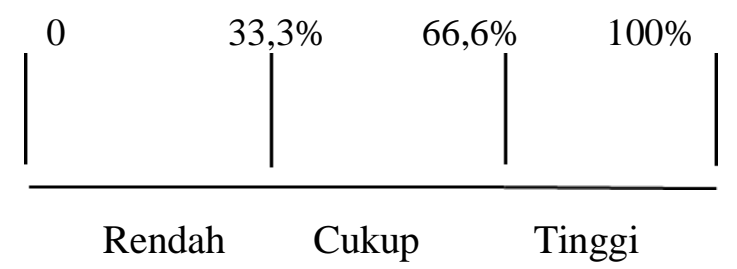

Keterangan kriteria Interprestasi skor tingkat motivasi:

Angka 0\%-33,3\% = Rendah

Angka 33,4\% - 66,6\% = Cukup

Angka 66,7 - 100\% = Tinggi

\section{HASIL DAN PEMBAHASAN}

\section{Deskripsi Wilayah Penelitian}

\section{Letak Geografis}

Desa Raanan Baru merupakan salah satu desa dengan luas wilayah 400 ha dan jarak dari Ibukota

Provinsi 94.1km. Desa Raanan Baru berada di Kecamatan Motoling Barat Kabupaten Minahasa

Selatan dengan batas wilayah sebagai berikut :

a. Sebelah Utara berbatasan dengan Desa Malola

b. Sebelah Selatan berbatasan dengan Desa Sebelah Toyopon dan Desa Keroit

c. Sebelah Timur berbatasan dengan Desa Motoling

d. Sebelah Barat berbatasan dengan Desa Tondey

\section{Keadaan Penduduk Menurut Jenis Kelamin}

Total keseluruhan jumlah penduduk yang ada di Desa Raanan Baru Kecamatan Motoling Barat Kabupaten Minahasa Selatan 1.125 jiwa. 
Tabel 1. Jumlah Penduduk Menurut Jenis Kelamin Petani Cabai di Desa Ranaan Baru.

\begin{tabular}{lccc}
\hline \multicolumn{4}{c}{ Cabai di Desa Ranaan Baru. } \\
No & Jenis Kelamin & $\begin{array}{c}\text { Jumlah } \\
\text { Penduduk } \\
\text { (Orang) }\end{array}$ & $\begin{array}{c}\text { Persentase } \\
(\mathbf{\%})\end{array}$ \\
\hline 1. & Laki-laki & 580 & 51,5 \\
2. & Perempuan & 545 & 48,4 \\
\hline \multicolumn{4}{r}{ Sumber $:$ Kantor Desa Raanan Baru Baru, 2020 }
\end{tabular}

Sumber : Kantor Desa Raanan Baru Baru, 2020

Tabel 1 menunjukkan jumlah penduduk berjenis kelamin laki-laki sebanyak 580 jiwa atau $51,5 \%$ dan jumlah penduduk berjenis kelamin perempuan sebanyak 545 jiwa atau $48,4 \%$ yang tersebar dalam (tujuh jaga).

\section{Jumlah Penduduk Menurut Tingkat Pendidikan}

Tingkat pendidikan di desa Raanan Baru Kecamatan Motoling Barat Kabupaten Minahasa Selatan.

\begin{tabular}{|c|c|c|c|}
\hline No. & Tingkat Pendidkan & $\begin{array}{l}\text { Jumlah } \\
\text { Penduduk } \\
\text { (Orang) }\end{array}$ & $\begin{array}{c}\text { Persentase } \\
(\%)\end{array}$ \\
\hline 1 & Tidak perna sekolah & 39 & 3,56 \\
\hline 2 & Belum/Tidak Tamat SD & 56 & 5,12 \\
\hline 3 & Tamat SD & 262 & 23,95 \\
\hline 4 & SLTA/Sederajat & 381 & 4,66 \\
\hline 5 & SLTP & 305 & 34,83 \\
\hline \multirow[t]{2}{*}{6} & Perguruan Tinggi & 51 & 27,88 \\
\hline & Jumlah & 1094 & 100 \\
\hline
\end{tabular}

Sumber : Kantor Desa Raanan Baru, 2020

Berdasarkan data diatas menunjukkan bahwa pendidikan masyarakat tersebar pada semua tingkat pendidikan yang tidak perna sekolah sebanyak 39 orang atau 3,56 persen, belum/tidak tamat SD sebanyak 56 orang atau 5,12 persen, tamat SD sebanyak 262 orang atau 23,95 persen, yang tamat SMP sebanyak 305 orang atau 27,88 persen, tamat SMA sebanyak 381 orang atau 34,83 persen, dan Perguruan Tinggi sebanyak 51 orang atau 4,66 persen.

\section{Karakteristik Responden}

\section{Umur Responden}

Kemampuan petani bekerja, berpikir, melakukan aktifitas secara fisik sangat dipengaruhi faktor umur. Petani yang memiliki umur muda tentunya memiliki kondisi fisik yang lebih kuat serta memiliki daya berpikir yang lebih kreatif dibandingkan yang berumur tua.
Tabel 3. Distribusi Responden Menurut Umur Petani Cabai di Desa Ranaan Baru

\begin{tabular}{cccc}
\hline \multicolumn{4}{c}{ di Desa Ranaan Baru } \\
No & Umur & $\begin{array}{c}\text { Jumlah } \\
\text { Penduduk } \\
\text { (Orang) }\end{array}$ & $\begin{array}{c}\text { Persentase } \\
(\%)\end{array}$ \\
\hline 1 & $20-30$ & 19 & 63,3 \\
2 & $31-40$ & 6 & 20 \\
3 & $41-60$ & 5 & 16,6 \\
\hline & Jumlah & $\mathbf{3 0}$ & $\mathbf{1 0 0}$ \\
\hline
\end{tabular}

Sumber: Diolah dari Data Primer, 2020

Data di atas menunjukkan bahwa jumlah responden dalam umur 20-30 menunjukkan yaitu paling sedikit 5 responden persentase 16,6 persen, usia 31-40 tahun menunjukkan 6 responden persentase 20 persen, usia 41-60 tahun menunjukkan persentase sebanyak 63,3 persen.

Tabel 4. Pengunaan Bibit Keluarga Petani Cabai di Desa Ranaan Baru

\begin{tabular}{clcccc}
\hline \multicolumn{6}{c}{ Ranaan Baru } \\
No & \multicolumn{1}{c}{ Bibit } & Skor & $\begin{array}{c}\text { Jumlah } \\
\text { Responden }\end{array}$ & $\begin{array}{c}\text { Persentase } \\
(\boldsymbol{\%})\end{array}$ & $\begin{array}{c}\text { Total } \\
\text { Skor }\end{array}$ \\
\hline 1. & $\begin{array}{l}\text { Ada, } \\
\text { Perjanjian } \\
\text { antara Petani } \\
\text { dan } \\
\text { pedagang } \\
\text { Ada, tanpa } \\
\text { perjanjian } \\
\text { Tidak ada }\end{array}$ & 3 & 23 & 76,6 & 69 \\
3. & 1 & 4 & 13,3 & 8 \\
\hline \multicolumn{1}{c}{ Jumlah } & 3 & 10,0 & 3 \\
\hline Sumber: Diolah dari Data Primer, 2020 & 30 & 100 & 80 \\
\hline
\end{tabular}

\section{Jumlah Responden Menurut Tingkat Pendidikan}

Peranan pendidikan formal sangat penting dalam usaha peningkatan kualitas seseorang karena berguna dalam pembangunan pribadi serta peningkatan intelektual dan wawasan seseorang.

Tabel 5. Distribusi Responden Menurut Tingkat Pendidikan

\begin{tabular}{cccc}
\multicolumn{4}{c}{ Petani Cabai di Desa Ranaan Baru } \\
No & Tingkat pendidikan & $\begin{array}{c}\text { Jumlah } \\
\text { Responden } \\
\text { (Orang) }\end{array}$ & $\begin{array}{c}\text { Persentase } \\
(\%)\end{array}$ \\
\hline 1 & SD & 16 & 53,3 \\
2 & SMP & 6 & 20 \\
3 & SMA-Sarjana & 8 & 26,6 \\
\hline & Jumlah & 30 & 100 \\
\hline
\end{tabular}

Sumber: Diolah dari Data Primer, 2020

Berdasarkan data diatas menunjukan tingkat SD 8 responden dengan persentase 26,6 persen, SMP sebanyak 6 responden 20 persen, SMA sebanyak 12 responden 40 persen, dan Sarjana 4 responden 13,3 persen.

\section{Luas Lahan yang Dimiliki (Ha)}

Keadaan lahan dan luas lahan akan mempengaruhi besarnya jumlah produksi dan penggunaan tenaga kerja. Lahan yang di kelola dengan baik. 


\begin{tabular}{cccc}
\multicolumn{4}{c}{ Tabel 6. Lahan Milik Sendiri Petani Cabai di Desa Ranaan Baru } \\
\hline \multirow{2}{*}{ No. } & Luas Lahan(Ha) & $\begin{array}{c}\text { Jumlah Responden } \\
\text { (Orang) }\end{array}$ & $\begin{array}{c}\text { Persentase } \\
(\%)\end{array}$ \\
\hline $\mathbf{1}$ & $<0,4$ & 4 & 13,3 \\
$\mathbf{2}$ & $0,4-0,8$ & 16 & 53,3 \\
$\mathbf{3}$ & $>1$ & 10 & 33,3 \\
\hline & Jumlah & 30 & 100 \\
\hline
\end{tabular}

Sumber: Diolah dari Data Primer, 2020

Luas lahan petani cabai milik sendiri di Desa Raanan Baru yaitu < 0,4 Ha sebanyak 13,33 persen (4 orang), 0,4-0,8 Ha sebanyak 53,33 persen (16 orang) dan $>1$ Ha sebanyak 33,33 persen (10 orang).

\section{Lingkungan Ekonomi}

Lingkungan ekonomi yaitu kekuatankekuatan ekonomi yang ada dalam masyarakat dilokasi penelitian yang keberadaannya dapat mendorong atau menghambat petani dalam membudidayakan tanaman cabai. Lingkungan ekonomi yang diteliti adalah ketersediaan sarana produksi, serta adanya jaminan pasar.

\section{Bibit}

Suatu yang diperoleh dari benih, yang nantinya akan ditanam dan tumbuh di media penanamannya. Benih adalah biji buah atau biji kecil- kecil yang akan ditanam atau disemaikan.

Responden menurut bibit yaitu persentase paling sedikit 3 responden 10 persen, selanjutnya persentase responden 13,3 persen, persentase paling sebanyak 23 responden persentase 76,6 persen.

\section{Pupuk}

Pupuk adalah hara yang ditambahkan pada media tanam atau tanaman untuk mencukupi kebutuhan hara yang diperlukan tanaman sehingga mampu berporduksi dengan baik.

Tabel 7. Pengunaan Pupuk dengan Cara Pembayaran Petani Cabai di Desa Ranaan Baru

\begin{tabular}{cccccc}
\hline No & Pupuk & Skor & $\begin{array}{c}\text { Jumlah } \\
\text { Responden } \\
\text { (orang) }\end{array}$ & $\begin{array}{c}\text { Persentase } \\
(\mathbf{\%})\end{array}$ & $\begin{array}{c}\text { Total } \\
\text { skor }\end{array}$ \\
\hline $1 . \quad \begin{array}{l}\text { Dibayar } \\
\text { sebelum } \\
\text { panen }\end{array}$ & 3 & 2 & 6,6 & 6 \\
2. & $\begin{array}{l}\text { Dibayar } \\
\text { pada saat } \\
\text { transaksi } \\
\text { Dibayar } \\
\text { setelah } \\
\text { panen }\end{array}$ & 2 & 19 & 63,3 & 38 \\
\hline & 1 & 9 & 30 & 9 \\
\hline Jumlah & 30 & 100 & 53 \\
\hline Sumber: Diolah dari Data Primer, 2020
\end{tabular}

Tabel 7 menunjukkan jumlah responden di Desa Raanan Baru Kecamatan Motoling Barat, menurut pupuk yaitu persentase paling sedikit 2 responden 6,6 persen, 9 responden persentase 30 persen, persentase paling sebanyak 19 responden persentase 63,3 persen.

\section{Jaminan Pasar}

Adanya jaminan pasar yaitu adanya hal-hal yang menjamin pemasaran hasil sehingga memudahkan petani dalam melakukan pemasaran. Pengukuran dilakukan dengan melihat adanya jaminan pembelian, jaminan harga, serta sistem pembayaran.

Tabel 8. Jaminan Pasar Tempat Penjualan Petani Cabai di Desa Ranaan Baru

\begin{tabular}{cccccc}
\hline No & $\begin{array}{c}\text { Pasar } \\
\text { Cabai }\end{array}$ & Skor & $\begin{array}{c}\text { Jumlah } \\
\text { Responden } \\
\text { (orang) }\end{array}$ & $\begin{array}{c}\text { Persentase } \\
(\%)\end{array}$ & $\begin{array}{c}\text { Total } \\
\text { skor }\end{array}$ \\
\hline 1. & 3 Tempat & 3 & - & & - \\
2. & 2 Tempat & 2 & 6 & 20 & 12 \\
3. & 1 tempat & 1 & 24 & 80 & 24 \\
\hline \multicolumn{2}{l}{ Jumlah } & & 30 & 100 & 38 \\
\hline
\end{tabular}

Sumber: Diolah dari Data Primer, 2020

Tabel 8 menunjukkan bahwa jumlah responden di Desa Raanan Baru Kecamatan Motoling Barat, menurut adanya jaminan pasar, yaitu sebesar 80 persen.

\section{Keuntungan Budidaya Cabai}

Keuntungan budidaya tanaman cabai yaitu berbagai kelebihan budidaya tanaman cabai secara teknis, yang meliputi tingkat kesesuaian potensi lahan, tingkat ketahanan terhadap resiko, tingkat penghematan waktu budidaya, dan tingkat kesesuaian dengan budaya setempat.

\section{Tingkat Kesesuaian Potensi Lahan}

Tingkat kesesuaian potensi lahan yaitu sesuai tidaknya lahan di wilayah tersebut untuk membudidayakan tanaman cabai. Pengukuran dilakukan dengan melihat kesuburan tanah.

Tabel 9. Tingkat Kesesuaian Potensi Lahan Petani Cabai di Dasa Ranaan Baru

\begin{tabular}{|c|c|c|c|c|c|}
\hline No & $\begin{array}{c}\text { Tingkat } \\
\text { kesesuaian } \\
\text { potensi }\end{array}$ & Skor & $\begin{array}{c}\text { Jumlah } \\
\text { Responden } \\
\text { (Orang) }\end{array}$ & $\begin{array}{c}\text { Persentase } \\
(\%)\end{array}$ & $\begin{array}{l}\text { Total } \\
\text { skor }\end{array}$ \\
\hline 1. & $\begin{array}{l}\text { Tanah } \\
\text { tanpa di } \\
\text { pupuk }\end{array}$ & 3 & 10 & 33,3 & 30 \\
\hline 2. & $\begin{array}{l}\text { Lebih baik } \\
\text { jika tidak } \\
\text { pupuk }\end{array}$ & 2 & 1 & 3,3 & 2 \\
\hline 3. & $\begin{array}{l}\text { Dipupuk } \\
\text { dengan } \\
\text { pupuk } \\
\text { organik }\end{array}$ & 1 & 19 & 63,3 & 19 \\
\hline & \multicolumn{2}{|c|}{ Jumlah } & 30 & 100 & 51 \\
\hline
\end{tabular}

Tabel 9 menunjukkan bahwa petani di desa Raanan Baru Kecamatan Motoling Barat, menurut tngkat kesesuaian potensi lahan yaitu persentase tanah yang jika tidak pupuk organik 1 responden dengan persentase 3,3 persen, selanjutnya petani cabai mengunakan pupuk organik 19 responden persentase 63,4 persen, tanah tanpa di pupuk 10 responden dengan persentase 33,3 persen. 


\section{Tingkat Ketahanan Terhadap Resiko}

Tingkat ketahanan terhadap resiko yaitu tahannya tanaman cabai terhadap ketidakpastian yang dapat menimbulkan kerugian.

Tabel 10. Tingkat Ketahanan Terhadap Resiko Petani Cabai di Desa Ranaan Baru

\begin{tabular}{|c|c|c|c|c|c|}
\hline No & $\begin{array}{c}\text { Tingkat } \\
\text { Ketahanan } \\
\text { Terhadap } \\
\text { Resiko } \\
\end{array}$ & Skor & $\begin{array}{c}\text { Jumlah } \\
\text { Responden } \\
\text { (Orang) }\end{array}$ & $\begin{array}{c}\text { Persentase } \\
(\%)\end{array}$ & $\begin{array}{l}\text { Total } \\
\text { skor }\end{array}$ \\
\hline 1. & Tahan & 3 & 12 & 40 & 36 \\
\hline 2. & $\begin{array}{c}\text { Cukup } \\
\text { tahan }\end{array}$ & 2 & 17 & 56,6 & 34 \\
\hline 3. & $\begin{array}{l}\text { Tidak } \\
\text { tahan }\end{array}$ & 1 & 1 & 3,3 & 1 \\
\hline & \multicolumn{2}{|c|}{ Jumlah } & 30 & 100 & 71 \\
\hline
\end{tabular}

Sumber: Diolah dari Data Primer, 2020

Tabel 10 menunjukkan responden menurut tingkat ketahanan terhadap resiko tanah di Desa Ranaan Baru tidak tahan 1 responden dengan persentase 3,3 persen dan tanah yang cukup tahan 17 responden persentase 56,6 persen, tanah yang tahan 12 responden persentase 40 persen.

\section{Tingkat Penghematan Waktu Budidaya.}

Tingkat penghematan waktu budidaya yaitu lamanya waktu yang dapat dikurangi untuk kegiatan budidaya, seperti olah lahan, persiapan bibit, pembenihan serta perawatan.

\begin{tabular}{|c|c|c|c|c|c|}
\hline No. & $\begin{array}{l}\text { Tingkat Penghematan } \\
\text { Waktu Budidaya }\end{array}$ & Skor & $\begin{array}{c}\text { Jumlah } \\
\text { Responden } \\
\text { (Orang) }\end{array}$ & $\begin{array}{c}\text { Perse } \\
\text { ntase } \\
(\%)\end{array}$ & $\begin{array}{c}\text { Tota } \\
1 \\
\text { skor }\end{array}$ \\
\hline 1. & $\begin{array}{l}\text { Membutuhkan } \\
\text { waktu budidaya } \\
\text { yang sedikit ( } 3 \\
\text { bulan) }\end{array}$ & 3 & 18 & 60 & 54 \\
\hline 2. & $\begin{array}{l}\text { Membutuhkan } \\
\text { waktu budidaya } \\
\text { yang sedang ( } 4 \\
\text { bulan) }\end{array}$ & 2 & 8 & 26,6 & 16 \\
\hline 3. & $\begin{array}{l}\text { Membutuhkan } \\
\text { waktu budidaya } \\
\text { yang lama } \\
\text { (5bulan) }\end{array}$ & 1 & 4 & 13,3 & 4 \\
\hline & Jumlah & & 30 & 100 & 74 \\
\hline
\end{tabular}

Tabel 11 menunjukkan menurut tingkat penghematan waktu budidaya petani mengaku panen pertama paling sedikit (3 bulan) 18 responden paling banyak dengan persentase 60 persen, dan petani mengaku waktu budidaya yang sedang ( 4 bulan) 8 responden dengan persentase 26,6 persen, dan waktu budidaya yang lama (5 bulan) 4 responden dengan persentase 13,3 persen.

\section{Pendapatan}

Pendapatan diukur dengan menghitung besarnya perolehan yang diterima petani. Besarnya pendapatan tersebut dapat digunakan untuk melihat pemenuhan

Tabel 12. Rata-rata Pendapatan Petani Cabai di Desa Ranaan Baru

\begin{tabular}{|c|c|c|c|}
\hline No. & $\begin{array}{c}\text { Pendapatan } \\
\text { (Rp/Panen) }\end{array}$ & $\begin{array}{c}\text { Jumlah } \\
\text { Responden } \\
\text { (Orang) }\end{array}$ & $\begin{array}{c}\text { Persentase } \\
(\%)\end{array}$ \\
\hline 1. & $<$ Rp500.000 & 5 & 16,7 \\
\hline 2. & $\begin{array}{c}\text { Rp600.000- } \\
1.000 .000\end{array}$ & 2 & 6,7 \\
\hline 3. & $>\mathrm{Rp} 1.100 .000$ & 23 & 76,6 \\
\hline & Jumlah & 30 & 100 \\
\hline
\end{tabular}

Sumber: Diolah dari Data Primer, 2020

kebutuhan keluarga petani.

Jumlah pendapatan Responden di Desa Raanan Baru Kecamatan Motoling Barat, menunjukkan responden menurut pendapatan yaitu paling sedikit 2 responden dengan persentase 6,7 persen, responden yang memiliki pendapatan $<$ Rp500.000 berjumlah 5 responden dengan persentase 16,7 persen, dan persentase paling banyak yaitu 23 responden dengan persentase 76,6 persen.

\section{Motivasi Petani dalam Budidaya Tanaman Cabai}

Motivasi petani diartikan sebagai suatu kondisi yang mendorong seseorang untuk melaksanakan suatu tindakan dalam rangka mencapai tujuannya.

\section{Tingkat Motivasi ekonomi dan Motivasi Sosiologis}

Motivasi ekonomi yaitu kondisi yang mendorong petani untuk memenuhi kebutuhan ekonomi. sedangkan motivasi sosiologis yaitu kondisi yang mendorong petani untuk memenuhi kebutuha sosial dan berinteraksi dengan orang lain karena petani hidup bermasyarakat.

Tabel 13. Tingkat Motivasi Ekonomi Petani Cabai di Desa

Ranaan Baru

\begin{tabular}{llcccc}
\hline $\begin{array}{l}\text { N } \\
\text { o }\end{array}$ & $\begin{array}{l}\text { Motivasi } \\
\text { Ekonomi }\end{array}$ & Skor & $\begin{array}{c}\text { Jumlah } \\
\text { Responden }\end{array}$ & $\begin{array}{c}\text { Persentase } \\
(\%)\end{array}$ & $\begin{array}{c}\text { Total } \\
\text { Skor }\end{array}$ \\
\hline 1 & Keinginan & 3 & 28 & 93,4 & 84 \\
& untuk & 2 & 1 & 3,3 & 2 \\
& memenuhi & 1 & 1 & 3,3 & 1 \\
& $\begin{array}{l}\text { kebutuhan } \\
\text { hidup }\end{array}$ & & & & \\
& keluarga & & & &
\end{tabular}




\begin{tabular}{|c|c|c|c|c|c|}
\hline 2 & Keinginan & 3 & 29 & 96,7 & 87 \\
\hline & untuk & 2 & - & - & - \\
\hline & $\begin{array}{l}\text { memperoleh } \\
\text { pendapatan }\end{array}$ & 1 & 1 & 3,3 & 1 \\
\hline & $\begin{array}{ll}\text { yang lebih } \\
\text { tinggi }\end{array}$ & & & & \\
\hline 3 & Keinginan & 3 & 10 & 33,3 & 30 \\
\hline & untuk & 2 & 4 & 13,3 & 8 \\
\hline & $\begin{array}{l}\text { membeli } \\
\text { barang } \\
\text { mewah }\end{array}$ & 1 & 16 & 53,3 & 16 \\
\hline 4 & Keinginan & 3 & 21 & 70,0 & 63 \\
\hline & untuk & 2 & 8 & 26,7 & 16 \\
\hline & $\begin{array}{l}\text { memiliki dan } \\
\text { meningkatka } \\
\mathrm{n} \text { tabungan }\end{array}$ & 1 & 1 & 3,3 & 1 \\
\hline 5 & Keinginan & 3 & 30 & 100 & 90 \\
\hline & untuk hidup & 2 & - & - & - \\
\hline & $\begin{array}{l}\text { lebih } \\
\text { sejahtera atau } \\
\text { lebih baik }\end{array}$ & 1 & 1 & - & - \\
\hline & Jumlah & & 30 & 500 & 399 \\
\hline
\end{tabular}

Sumber: Diolah dari Data Primer, 2020

Tabel 13 menunjukkan tingkat motivasi ekonomi dapat diketahui bahwa tingkat motivasi ekonomi responden dimana keinginan untuk hidup lebih sejahtra atau hidup lebih baik memiliki persentase tertinggi yaitu 100 persen, bahwa responden menanam tanaman cabai dengan harapan yang tinggi dapat memenuhi kebutuhan ekonominya. Mata pencaharian pokok responden adalah sebagai petani. Tujuan utama budidaya tanaman cabai yang dilakukan responden adalah untuk memenuhi kebutuhan ekonominya, termasuk keinginan dalam memenuhi kebutuhan hidup keluarga, keinginan untuk memperoleh pendapatan yang lebih tinggi, keinginan untuk membeli. barang-barang mewah, keinginan untuk memiliki dan meningkatkan tabungan, serta keinginan untuk hidup lebih sejahtera atau hidup lebih baik. Total skor yang diperoleh dari 30 Responden pada pertanyaan no 6 adalah 399. Cara perhitungan skor dengan mengunakan skala likert jumlah skor ideal tinggi (900), Angka indeks partisipasi mengenai pertanyaan nomor 6 yaitu : 399/90 x $100=443,3$ persen sehingga interpretasi nilainya tergolong rendah. Dari data yang dihimpun sebanyak 5 pertanyaan yang diajukan kepada kepada 30 responden maka diperoleh total skor 443,3 persen.

Tabel 14. Tingkat Motivasi Sosiologis Petani Cabai di Desa

\begin{tabular}{llcccc}
\multicolumn{6}{c}{ Ranaan Baru } \\
No. & $\begin{array}{l}\text { Motivasi } \\
\text { Sosiologis }\end{array}$ & Skor & $\begin{array}{c}\text { Jumlah } \\
\text { Responden }\end{array}$ & $\begin{array}{c}\text { Persentase } \\
(\%)\end{array}$ & $\begin{array}{c}\text { Total } \\
\text { Skor }\end{array}$ \\
\hline 1. & Keinginan & 3 & 22 & 73,4 & 66 \\
& untuk & 2 & 4 & 13,3 & 8 \\
& menambah & 1 & 4 & 13,3 & 4 \\
& relasi atau & & & & \\
& teman & & & & \\
2. & Keinginan & 3 & 26 & 86,7 & 78 \\
& untuk & 2 & 1 & 3,3 & 2 \\
& bekerjasama & 1 & 3 & 10,0 & 3
\end{tabular}

\begin{tabular}{|c|c|c|c|c|c|}
\hline & $\begin{array}{l}\text { dengan } \\
\text { orang lain }\end{array}$ & & & & \\
\hline \multirow[t]{3}{*}{3.} & Keinginan & 3 & 28 & 93,3 & 84 \\
\hline & untuk & 2 & 1 & 3,3 & 2 \\
\hline & $\begin{array}{l}\text { mempererat } \\
\text { kerukunan }\end{array}$ & 1 & 1 & 3,3 & 1 \\
\hline \multirow[t]{3}{*}{4.} & Keinginan & 3 & 28 & 93,3 & 84 \\
\hline & untuk dapat & 2 & - & - & - \\
\hline & $\begin{array}{l}\text { bertukar } \\
\text { pendapat }\end{array}$ & 1 & 2 & 6,7 & 2 \\
\hline \multirow[t]{4}{*}{5.} & Keinginan & 3 & 24 & 80 & 72 \\
\hline & untuk & 2 & 6 & 20 & 12 \\
\hline & $\begin{array}{l}\text { mendapat } \\
\text { bantuan dari } \\
\text { pihak lain }\end{array}$ & 1 & - & - & - \\
\hline & Jumlah & & 30 & 500 & 418 \\
\hline
\end{tabular}

Tabel 14 menunjukkan menurut tingkat motivasi sosiologis dapat diketahui bahwa motivasi sosiologis responden berada pada kategori tinggi, yaitu sebanyak 93,3 persen atau 28 orang. Artinya bahwa responden beranggapan bahwa menanam tanaman cabai dapat membawa dampak positif secara sosial yaitu dapat mempererat persaudaraan antar petani sehingga terjalin kerjasama yang baik.

Adanya kerjasama yang baik tersebut maka responden dapat bertukar pengalaman dan informasi, terutama informasi yang bermanfaat untuk peningkatan usahatani mereka. Terkait dengan keinginan untuk menambah relasi atau teman, keinginan untuk bekerjasama dengan orang lain, keinginan untuk mempererat kerukunan, keinginan untuk dapat bertukar pendapat, dan keinginan untuk dapat memperoleh bantuan dari pihak lain, hal ini bisa muncul meskipun petani tidak membudidayakan tanaman cabai. Keinginan itu pasti ada, tetapi dengan budidaya tanaman cabai, petani semakin mempunyai hubungan sosial yang lebih dekat.

Total skor yang diperoleh dari 30 Responden pada pertanyaan no 7 adalah 418 . Cara perhitungan skor dengan mengunakan skalah likert jumlah skor ideal tinggi (900), Angka indeks motivasi sosiologis mengenai pertanyaan nomor 7 yaitu: 418/90 x 100 $=464,4$ persen sehingga interpretasi nilainya tergolong rendah. Dari data yang dihimpun sebanyak 5 pertanyaan yang diajukan kepada kepada 30 responden maka diperoleh total skor 418 persen. maka perlu dihitung dengan jumlah keseluruhan skor mencapai 817. Pada penelitian di hitung dengan mengunakan 
skalah likert jumlah skor ideal atau skor tertinggi yaitu 900 dan jumlah skor terendah adalah 300 . Dari data yang dihimpun sebanyak 10 pertanyaan yang diajukan kepada kepada 30 responden maka diperoleh total skor 817. Secara persentase angka indeks tingkat motivasi ekonomi dan motivasi sosilogis di Desa Raanan Baru Kecamatan Motoling Barat Kabupaten Minahasa Selatan terletak pada :

Tingkat motivasi ekonomi dan motivasi sosiologis $=\frac{817}{900} \times 100 \%$

$$
=90,7 \%
$$

Tabel 15.Rekapitulasi Skor Interpretasi Tingkat Motivasi Ekonomi dan Sosiologis

\begin{tabular}{|l|l|l|l|l|}
\hline NO & Pertanyaan memenuhi & $\begin{array}{l}\text { Total } \\
\text { skor }\end{array}$ & $\begin{array}{l}\text { Indeks } \\
\text { Tingkat }\end{array}$ & Interpretasi \\
\hline 1 & $\begin{array}{l}\text { Keinginan untuk } \\
\text { kebutuhan hidup keluarga }\end{array}$ & 96,6 & Tinggi \\
\hline 2 & $\begin{array}{l}\text { Keinginan untuk memperoleh } \\
\text { pendapatan yang lebih tinggi }\end{array}$ & 88 & 97,7 & Tinggi \\
\hline 3 & $\begin{array}{l}\text { Keinginan untuk membeli barang- } \\
\text { barang mewah }\end{array}$ & 54 & 60 & Cukup \\
\hline 4 & $\begin{array}{l}\text { Keinginan untuk memiliki dan } \\
\text { meningkatkan tabungan }\end{array}$ & 80 & 88,8 & Tinggi \\
\hline 5 & $\begin{array}{l}\text { Keinginan untuk hidup lebih } \\
\text { sejahtera atau hidup lebih baik }\end{array}$ & 90 & 100 & Tinggi \\
\hline 6 & $\begin{array}{l}\text { Keinginan untuk menambah relasi } \\
\text { atau teman }\end{array}$ & 78 & 86,6 & Tinggi \\
\hline 7 & $\begin{array}{l}\text { Keinginan untuk bekerjasama dengan } \\
\text { orng lain }\end{array}$ & 83 & 92,2 & Tinggi \\
\hline 8 & $\begin{array}{l}\text { Keinginan untuk mempererat } \\
\text { kerukunan }\end{array}$ & 87 & 96,6 & Tinggi \\
\hline 9 & $\begin{array}{l}\text { Keinginan untuk dapat bertukar } \\
\text { pendapat }\end{array}$ & 86 & 95 & Tinggi \\
\hline 10 & $\begin{array}{l}\text { Keinginan untuk mendapat bantuan } \\
\text { dari pihak lain }\end{array}$ & 84 & 93,3 & Tinggi \\
\hline
\end{tabular}

Berdasarkan hasil analisis menggunakan Skala Likert maka dapat diketahui bahwa angka indeks Motivasi Ekonomi dan Motivasi Sosiologi berada pada titik 90,7 persen dan tergolong tinggi. Secara keseluruhan dari penelitian ini tergambar dalam rekapitulasi jumlah skor motivasi ekonomi dan sosiologis pada kegiatan lainnya semuanya tergolong tinggi.

\section{KESIMPULAN DAN SARAN}

\section{Kesimpulan}

1. Motivasi petani dalam budidaya tanaman cabai di Desa Raanan Baru didapatkan yaitu motivasi sosiologis memiliki nilai interpretasi yang tinggi yaitu 443,3 persen dengan harapan dapat memenuhi kebutuhan ekonominya motivasi sosioligis muncul karena adanya keinginan untuk mempererat kerukunan dan bertukar pendapat sesama petani cabai. Motivasi ekonomi memiliki interpretasi nilai yang tinggi dengan persentase 464 persen. Motivasi ekonomi muncul karena adanya keinginan untuk mendapatkan pendapatan yang lebih tinggi dan dapat membawa dampak positif.

2. Motivasi petani dalam budidaya tanaman cabai di Desa Raanan Baru adalah faktor internal meliputi umur yang berada pada kategori 20 sampai 30 tahun dan tingkat pendidikan. Tingkat pendidikan SD lebih termotivasi daripada tingkat pendidikan yang lebih tinggi. Faktor eksternal yang memotivasi petani adalah ketersediaan sarana produksi yaitu bibit dengan adanya perjanjian antara petani dan pedagang yang sekaligus adalah penjual bibit. Keuntungan budidaya tanaman cabai yang memotivasi petani yaitu tingkat ketahanan terhadap resiko, tingkat penghematan waktu budidaya, penghematan waktu budidaya termasuk dalam kategori cepat yaitu hanya membutuhkan 30 hari dari bibit hingga panen pertama dan panen berikutnya hanya setiap 10 hari.

\section{Saran}

Berdasarkan kesimpulan maka disarankan

1. Petani cabai di Desa Raanan Baru Kecamatan Motoling Barat Kabupaten Minahasa Selatan harus menyadari bahwa dalam budidaya tanaman cabai, teknik dalam peningkatan produksi sangat penting dan harus diterapkan dengan cara seperti kebutuhan pupuk, bibit yang digunakan dalam proses budidaya sehingga tanaman cabai mampu berkembang serta memperoleh hasil produksi yang optimal sehingga mendapatkan penghasilan yang lebih dan mampu untuk memenuhi kebutuhan hidup.

2. Dapat kiranya Penyuluh Pertanian Lapang (PPL) memberikan kegiatan penyuluhan dilapangan agar memperkuat keyakinan petani dalam berbudidaya sehingga meningkatkan produktivitas tanaman cabai.

\section{DAFTAR PUSTAKA}

Hariandja, Marihot T. E. 2002.Manajemen Sumber Daya Manusia. Jakarta: Grasindo 
Hewindati,Y.T. 2006. Hortikultura. Universitas Terbuka. Jakarta.

Harpenas, Asep \& R. Dermawan. 2010. Budidaya Cabai Unggul. Penebar Swadaya. Jakarta

Kartono, Kartini, 2003. Pemimpin dan Kepemimpinan : Apakah Kepemimpinan abnormal Itu?, P. T Raja Grafindo Persada, Jakarta. 